\title{
The Relationship of a Balanced Nutrition Lifestyle in the Prevention of Corona Virus Disease 2019 (Covid-19) in Watotika Ile Village, Demon Pagong District, East Flores Regency, Nusa Tenggara Timur Province
}

\author{
Musfirah $^{1}$, Abdul Gafur ${ }^{2}$, Maria Andika \\ ${ }^{1,3}$ Department of Public Health, Sekolah Tinggi Ilmu Kesehatan Tamalate, Makassar , Indonesia \\ ${ }^{2}$ Department of Public Health, University of Pejuang Republic of Indonesia, Makassar, Indonesia
}

Corresponding Author: Abdul Gafur

\begin{abstract}
Introduction: Coronavirus is a virus that can cause illness or health problems with either mild symptoms or severe symptoms even to death, this virus can pass from one person to another through small droplets or splashes. when someone coughs or sneezes, these droplets can be directly exposed to people around or through objects touched by others which then touch the nose, eyes, mouth and finally until the person is infected with the virus. This study aims to determine the relationship between a balanced nutritional lifestyle in the prevention of Corona Virus Disease 2019 (COVID-19) in Watotika Ile Village, Demon Pagong District, East Flores Regency, Nusa Tenggara Timur (NTT) Province.

Methods: This research was conducted using analytic survey, quantitative method with cross sectional study approach. The sample of this study was taken by purposive sampling with a total sample of 107 respondents. The research instrument used a questionnaire, the Food Frequency Questionnaire (FFQ) form and the International Physical Activity Questionnaire (IPAQ) guide. Analysis of quantitative data was done using the Chi-square test.
\end{abstract}

Result: The results of the study from 107 respondents based on the chi-square test of significance, there was a relationship between the habit of consuming various foods with the prevention of Corona Virus Disease 2019 (COVID-19) with a Value of $0.008(\rho<0.05)$, there was a relationship between a clean lifestyle and prevention efforts. Corona Virus Disease 2019 (COVID-19) with value 0.030 $(\rho<0.05)$, there is a relationship between physical activity and efforts to prevent Corona Virus Disease 2019 (COVID-19) with value $0.020(\rho<0.05)$.

Conclusion: There is a relationship between the habit of consuming a variety of foods, a clean lifestyle and physical activity with efforts to prevent COVID-19. There is a relationship between a clean lifestyle and efforts to prevent COVID-19.

Keywords: Habits of eating diverse foods, clean lifestyle, physical activity, Corona Virus

Disease (COVID 19)

\section{INTRODUCTION}

Coronavirus is a virus that can cause illness or health problems, both with mild symptoms and even severe symptoms. until death, this virus can pass from one person to another through small droplets or splashes when someone coughs or sneezes, these droplets can be directly exposed to people around or through objects touched by others which then touch the nose, eyes, mouth and finally until the person is infected with the virus. ${ }^{1}$

Covid-19 was initially identified in China, precisely in Wuhan City, where in early January 2020 many people were 
affected by a new type of pneumonia whose cause was not known until it was finally referred to as a new type of Coronavirus, from the problem of cases in the city. It is this Wuhan that continues to grow throughout the world causing morbidity and mortality and makes WHO declare this problem a global public health emergency. ${ }^{2}$

Covid-19 cases until this research took place have spread to all corners of the world quickly with a total case of $25,170,439$ people. The highest cases were the United States with approximately 6 million cases, followed by Brazil with 3.8 million and India with 3.5 million. $^{2}$

In Indonesia itself until this research took place as of August 30, 2020 there were 172,053 positive cases with a death rate of 7,343 people with a recovery rate of 124,185 people, Nusa Tenggara Timur (NTT) is one of the provinces that is also affected by this global problem, where data The Ministry of Health in 2020 recorded 152 positive cases with a death rate of 1 and a cure rate of 130. Based on data obtained from the Task Force for the Acceleration of Handling Covid 19 in East Flores Regency there were 17 travelers who were in quarantine and of these 17 people based on the results Swab there are 2 people who are declared positive. Therefore, researchers are interested in conducting research on the Relationship of a Balanced Nutrition Lifestyle in Efforts to Prevent Corona Virus Disease 2019 (COVID-19) in Watotika Ile Village, Demon Pagong District, East Flores Regency. ${ }^{3}$

Some of the things above in an effort to prevent COVID-19 are also required for optimal body defense. One of them is by eating a balanced diet. Consumption of adequate nutrition is very important for the immune system which will protect us from diseases caused by viruses and prevent other diseases.

In the midst of this pandemic, people need to adopt a healthy lifestyle with balanced nutrition in order to increase body resistance. Because, with an excellent immune system, a person will not be easily infected with COVID-19 in terms of nutrition. Consuming a variety of foods, in accordance with balanced nutrition guidelines, namely the composition of daily food containing nutrients in the same type and amount according to the body's needs by taking into account the principles of food diversity, physical activity, clean living behavior and maintaining a normal body weight to prevent nutritional problems. Consumption of foods with balanced and safe nutrition can boost the immune system and reduce the risk of chronic diseases and infectious diseases. Eating nutritious foods is very important to build a strong immune system to be protected from viral infections, as well as provide extra protection for the body. The contents of the daily dinner plate should consist of; staple food which is a source of carbohydrates, side dishes are a source of protein, vegetables and fruit are a source of vitamins, minerals. Especially colorful vegetables and fruits, contain lots of vitamins and function as antioxidants, namely vitamins $\mathrm{A}, \mathrm{C}, \mathrm{E}$. In addition to protein, carbohydrate, fat intake, attention must be paid to the body's defense against viruses, one must also pay attention to the intake of vitamins and minerals such as vitamins A, B, C, D, E, omega 3 fatty acids, selenium, zinc, iron. ${ }^{4}$

Implement a clean life by getting used to clean and healthy living behavior. Must wash hands before eating. Washing hands is the main pillar to prevent infections that enter through the hands, because hands are a source of direct or indirect transmission of germs. This explains that there is a reciprocal relationship between infection and nutritional status. Good nutritional status increases endurance. High immune system causes not easily infected with viruses or bacteria.

Based on the results of research conducted by Merry, et al., it shows that there is a significant relationship between PHBS and the incidence of infectious diseases (diarrhea). This is in accordance with the statement that bad behavior will make a major contribution to causing 
Province.

diarrheal pain. Hygiene behavior is one of the targets for PHBS. Where the notion of hygiene behavior itself is an activity or action that has the aim of increasing public awareness about personal and environmental health, which includes several clean habits which are one of the efforts in preventing diarrheal disease. ${ }^{5}$

Good immune status can prevent various diseases, for example, diseases caused by bacteria or viruses, one of which is Corona Virus Disease 2019 (COVID-19). Several risk factors that make a person susceptible to infection are poor nutritional status and reduced body resistance caused by many factors. One of the main components of the immune system is $\mathrm{T}$ cells, a form of white blood cells (lymphocytes) that function to find types of pathogens and destroy them. If a person is less able to produce lymphocytes for the immune system, the infection-fighting cells produced are less responsive and less effective. ${ }^{6}$

The wrong diet can lead to a lack of intake of nutrients needed by a person such as protein, vitamin $\mathrm{A}$, vitamin $\mathrm{C}$ and several other nutrients that play a role in the body's immune function. All these nutrients are met if we can apply the role of balanced nutrition. ${ }^{7}$

\section{RESEARCH METHODS}

The research design used in this study was an analytical survey. By using a cross sectional study approach, which is a form of observational (non-experimental) study to find the relationship between the independent variable and the dependent variable by taking concurrent measurements, the research was conducted by analyzing the relationship between a Balanced Nutrition Pattern in the Prevention of Corona Virus Disease 2019 (COVID-19) in Watotika Ile Village. The sample consists of an affordable part of the population that can be used as research subjects through sampling. The sample of this study was 107 people.

\section{RESEARCH RESULT}

Research data collection in July 2020 by conducting direct interviews with respondents who were met at the respondent's house and by telephone in Watotika Ile Village using a questionnaire, then the results of data collection were processed by statistical tests using an application. SPSS 22 can then be presented in tabular form as follows: The Relationship between the Independent Variables and the Prevention of COVID 19 in Watotika Ile Village, Demon Pagong District.

\begin{tabular}{|c|c|c|c|c|c|c|c|}
\hline \multirow[t]{3}{*}{ Independent Variabel } & \multicolumn{4}{|c|}{ Prevention of Corona Virus Disease (COVID 19) } & \multirow{2}{*}{\multicolumn{2}{|c|}{ Total }} & \multirow{3}{*}{$\rho$ value } \\
\hline & \multirow{2}{*}{$\begin{array}{l}\text { Yes } \\
\mathrm{n}\end{array}$} & \multirow[b]{2}{*}{$\%$} & \multicolumn{2}{|l|}{ No } & & & \\
\hline & & & $\mathrm{n}$ & $\%$ & $\mathrm{n}$ & $\%$ & \\
\hline \multicolumn{7}{|c|}{ Eating Habits of Diverse Food } & 0,008 \\
\hline Less & 22 & 78,6 & 6 & 21,4 & 28 & 100,0 & \\
\hline Enough & 23 & 76,7 & 7 & 23,3 & 30 & 100,0 & \\
\hline Good & 48 & 98,0 & 1 & 2,0 & 49 & 100,0 & \\
\hline \multicolumn{7}{|l|}{ Clean Lifestyle } & 0,030 \\
\hline Not Good & 78 & 90,7 & 8 & 9,3 & 86 & 100,0 & \\
\hline Good & 15 & 71,4 & 6 & 28,6 & 21 & 100 & \\
\hline \multicolumn{7}{|l|}{ Physical Activity } & 0,020 \\
\hline Mild & 13 & 92,9 & 1 & 7,1 & 14 & 100,0 & \\
\hline Medium & 37 & 97,4 & 1 & 2,6 & 38 & 100,0 & \\
\hline Height & 43 & 78,2 & 12 & 21,8 & 55 & 100,0 & \\
\hline
\end{tabular}

The table above shows that of the 107 respondents who have a good habit of eating diverse foods and preventing COVID-19 as many as 48 people $(98.0 \%)$. Meanwhile, 22 people $(78.6 \%)$ had a bad habit of consuming diverse foods and preventing COVID-19.
The results of statistical tests using the Pearson Chi-Square obtained a value of $=0.008$ where $\rho<(\alpha=0.05)$ then Ho is rejected and $\mathrm{Ha}$ is accepted or there is a significant relationship between the habit of eating a variety of foods with COVID-19 prevention efforts. 
Musfirah et.al. The relationship of a balanced nutrition lifestyle in the prevention of corona virus disease 2019 (Covid-19) in Watotika Ile Village, Demon Pagong District, East Flores Regency, Nusa Tenggara Timur Province.

Of the 107 respondents whose Clean Lifestyle is Not Good and have made efforts to prevent COVID-19 as many as 78 people $(90.7 \%)$. Meanwhile, 15 people $(71.4 \%)$ had a good clean lifestyle and made efforts to prevent COVID-19.

The results of statistical tests using Fisher's Exact Test obtained a value of = 0.030 where $<(\alpha=0.05)$ then Ho was rejected and $\mathrm{Ha}$ is accepted or there is a significant relationship between a Clean Lifestyle and COVID-19 Prevention Efforts.

Based on the physical activity variable, 43 people $(78.2 \%)$ out of 107 respondents who had high physical activity and made efforts to prevent COVID-19. While those who did light physical activity and made efforts to prevent COVID-19 were 13 people $(92.9 \%)$.

The results of statistical tests using Pearson Chi-Square obtained a value of $=$ 0.020 where $<(\alpha=0.05)$ then Ho is rejected and $\mathrm{Ha}$ is accepted or there is a significant relationship between physical activity and COVID-19 Prevention Efforts

\section{DISCUSSION}

\section{Consuming Diverse Food Habits}

General guidelines for balanced nutrition (2014), diverse foods, namely foods that contain elements of nutrients needed by the body both in quality and quantity, in nutrition science it is commonly called triguna food, namely, foods that contain energy, builders, and regulators.

The results showed that there was a relationship between the habit of consuming various foods and efforts to prevent COVID-19 $(\rho$ value $=0.008<0.05)$. This shows that the habit of eating a variety of foods affects efforts to prevent COVID-19.

The habit of consuming diverse foods in Watotika Ile Village is generally good, this can be seen from Table 5.6 which shows that from 107 respondents there are 49 people $(45.8 \%)$ who have a good habit of eating diverse foods, and 28 people (26, $2 \%$ ) whose habit of eating diverse foods is not good. This can be seen from the frequency of food ingredients consumed by the local community. Diverse food, in this case people in general have consumed a variety of foods such as staple foods, side dishes, vegetables and fruits. People generally assume that every meal there must be side dishes and vegetables, in this case at least fish and vegetables. As for the fruit is eaten if there is. Table 5.9 shows that of the 28 people whose habits of eating diverse foods are less but there are 22 people (78.6\%) who do this prevention because the people in Watotika Ile Village do prevention outside of the prevention of a balanced nutritional lifestyle where the prevention is keep your distance and wear a mask.

From the results of research conducted by Saragih, et al (2020) stated that out of 200 respondents there were 118 people $(59 \%)$ who experienced changes in eating habits. Increased diversity of food can occur the desire to have better nutrition and support to increase the body's immunity or immunity. Because the media has said that one of the antidotes to COVID-19 is to increase the body's immunity. The more variety of foods consumed, the more sources of nutrition obtained from food. ${ }^{8}$

Lack of nutrients contributes to infectious diseases and conversely infectious diseases cause malnutrition. People who suffer from malnutrition will be very susceptible to various diseases. This is due to the lack of nutritious food intake that can improve the body's immune system. Likewise, if a person is exposed to an infectious disease, his appetite will decrease so that if it is not handled it will cause malnutrition ${ }^{9}$.

In principle, there are two types of diseases, namely communicable diseases and non-communicable diseases. Corona Virus Disease 2019 (COVID-19) is one of the infectious diseases, while health problems that arise due to dietary errors such as diabetes, cholesterol are included in the category of non-communicable diseases. This means that the process of spreading the Corona virus actually has almost nothing to do with diet. 
Musfirah et.al. The relationship of a balanced nutrition lifestyle in the prevention of corona virus disease 2019 (Covid-19) in Watotika Ile Village, Demon Pagong District, East Flores Regency, Nusa Tenggara Timur Province.

The European Food Safety Association (EFSA) itself in its release on March 9, 2020 explained that food is part of the transmission route for Corona Virus Disease 2019 (COVID-19). However, even though eating is not an agent for spreading COVID-19 and is not the cause of the disease, eating patterns are closely related to the body's resistance when exposed to COVID-19. A person with a good diet, of course, has a better immune system than someone who has a bad diet.

\section{Clean Lifestyle}

According to the Ministry of Health (2014) a clean and healthy lifestyle must be accustomed to avoid infectious diseases. Infectious diseases such as diarrhea can be prevented by washing hands. Hand washing is an act of sanitation by cleaning hands and fingers using water and soap by humans to be clean and break the chain of germs. The results showed that there was a relationship between a clean lifestyle and efforts to prevent COVID-19 ( $\rho$ value $=0.030<0.05$ ). This shows that a clean lifestyle affects efforts to prevent COVID-19.

The clean lifestyle in Watotika Ile Village is still not good, it can be seen from 107 respondents there are 86 people (80.4\%) whose clean lifestyle is not good. People in general have not implemented a clean lifestyle, this is because people are not accustomed to washing their hands after doing something or after leaving the house. COVID-19 is a new type of disease so that people do not understand the cause of the disease and people are still at the bottom with old habits where they wash their hands properly, for example if their hands are dirty. Table 5.10 shows that from 86 people the clean lifestyle is not good but there are 78 people $(78.6 \%)$ who do this prevention because the people in Watotika Ile Village do prevention outside of the prevention of a balanced nutritional lifestyle where the prevention is taking care distance and use of masks.

Applying a clean life by getting used to clean and healthy living behavior, must wash hands before eating. Washing hands is the main pillar to prevent infections that enter through the hands, because hands are a source of direct or indirect transmission of germs. This explains that there is a reciprocal relationship between infection and nutritional status. Good nutritional status increases endurance. High immune system causes not easily infected with viruses or bacteria. Infectious diseases are one of the important factors that directly affect a person's nutritional status. A person suffering from an infectious disease will experience a decrease in appetite so that the amount and type of nutrients that enter the body decreases. On the other hand, in a state of infection, the body requires more nutrients to meet the increased metabolism in people suffering from infection, especially when accompanied by heat.

Clean and healthy living behavior is a strategy that can prevent the spread of COVID-19, the community is continuously encouraged to improve clean and healthy living behavior in an effort to prevent the spread of COVID-19, because community behavior can play an important role in reducing the spread of COVID-19 (Marni 2020). The application of a clean lifestyle is closely related to how hygiene and sanitation is food administration. With a clean lifestyle in the era of the COVID-19 pandemic, it is always emphasized. This virus can be prevented by always maintaining cleanliness. COVID-19 can be spread through close contact, and the environment or objects that are infected with the virus. The virus can also spread through droplets that come from the patient's respiratory tract. This is the same as COVID-19, which is a type of disease that attacks the respiratory tract and has the same symptoms as acute respiratory tract infections (ARI).

\section{Physical Activity Physical}

Activity which includes all kinds of body activities including sports is an effort to balance the expenditure and intake of nutrients, the main source of energy in the 
body. The results showed that there was a relationship between activities and efforts to prevent COVID 19 ( $\rho$ value $=0.020<0.05$ ). This shows that physical activity affects efforts to prevent COVID-19. The physical activity of the community in Watotika Ile Village belongs to the type of high activity, this can be seen in Table 5.8 of 107 respondents there are 55 people $(51.4 \%)$ who do high activity and 14 people $(13.1 \%)$ who do light activity. This is because the people in Watotikan Ile Village are generally farmers and housewives who always carry out strenuous activities such as looking for firewood.

The people of Watotika Ile Village do not do sports because their time is spent farming this indirectly they have been doing sports. This shows that indirectly the people of Watotika Ile Village have carried out physical activities to increase their body immunity, and indirectly they have also made efforts to prevent COVID-19. With a good immune system, the body is healthier and not easily tired, can prevent contracting the COVID-19 disease. Physical activity carried out regularly with moderate intensity can increase body resistance while physical activity with heavy intensity can cause a decrease in body resistance in the form of a decrease in lymphocytes so that the body is susceptible to infectious diseases. Table 5.11 shows that out of 14 people with light physical activity, there are 13 people (92.9\%) who do this prevention because the people in Watotika Ile Village do prevention outside of the prevention of a balanced nutritional lifestyle where the prevention is to keep a distance and use of masks.

Based on the results of research conducted by Faisal (2020) shows that the majority of people in Malang Regency, choose to do physical activity in this case sports to increase physical immunity as much as $45 \%$, but most of the respondents also choose the goal of sport is to participate in trending reaching 37\%. In accordance with the recommendation of the Association of Indonesian Sports Specialist Doctors (PDSKI) that during the pandemic, exercise should be carried out with the aim of maintaining body immunity.

Physical activity is one of several factors that affect the quality of life (Dewi, 2018). Physical activity that is done regularly with light to moderate intensity can improve body fitness. Such activities will improve and slow down the process of decreasing organ function and increase the work of blood cells which are the main components of the body's immunity in circulation, so as to protect the body from infection. This shows that doing enough activities can increase the body's resistance so that the body is not susceptible to infectious diseases such as Corona Virius Disease 2019 (COVID-19).

\section{CONCLUSION}

There is a relationship between the habit of consuming diverse foods, a clean lifestyle and physical activity with efforts to prevent COVID-19 There is a relationship between a clean lifestyle and efforts to prevent COVID-19.

\section{Acknowledgement: None}

Conflict of Interest: None

\section{Source of Funding: None}

\section{Ethical Approval: Approved}

\section{REFERENCES}

1. Burhan, E. (2020). Coronavirus yang Meresahkan Dunia. IDI.

2. WHO. (2020). Coronavirus Disease 2019 (COVID-19) Situation Reports. April 1 2020. WHO Situation Report, 2019(72), 119.

3. Gugus tugas Percepatan Penanganan Covid19. Data Covid-19. https://covid19.go.id

4. Kemenkes RI. (2020). Pedoman Pencegahan dan Pengendalian Coronavirus Disease (COVID-19). Germas.

5. Sander, M. A. 2005. Hubungan Faktor Sosio Budaya dengan Kejadian Diare di. Desa Candinegoro Kecamatan Wonoayu Sidoarjo. Jakarta: Jurnal Medika 
Musfirah et.al. The relationship of a balanced nutrition lifestyle in the prevention of corona virus disease 2019 (Covid-19) in Watotika Ile Village, Demon Pagong District, East Flores Regency, Nusa Tenggara Timur Province.

6. Fatmah. Respon imunitas yang rendah pada tubuh manusia lanjut usia. Jurnal Makara Kesehatan . 2006; 10(1):47-53.

7. Krenitsky J. Immunonutrition - fact, fancy or folly?. Dalam: Parish Cr, editor. Nutrition issues in gastroeneterology: practical enterologi. New York; 2006.

8. Saragih Bernatal. 2020 Hubungan Berbagai Faktor dengan Kebiasaan Makan pada Masa Pandemi Covid 19. Univeritas Mulawarman

9. Moehji, Sjahmien. 2003. Ilmu Gizi 2 Penaggulagan Gizi Buruk. Jakarta:Papas Sinar

How to cite this article: Musfirah, Gafur A, Andika M. The relationship of a balanced nutrition lifestyle in the prevention of corona virus disease 2019 (Covid-19) in Watotika Ile Village, Demon Pagong District, East Flores Regency, Nusa Tenggara Timur Province. International Journal of Science \& Healthcare Research. 2021; 6(2): 318-324. DOI: https:// doi.org/10.52403/ijshr.20210457 